\title{
Dynamic Comparative Advantages in the ASEAN+3
}

\author{
Tri Widodo \\ Gadjah Mada University
}

\begin{abstract}
This paper aims to investigate the dynamic changes in comparative advantage of the ASEAN, China, Republic of Korea and Japan (commonly abbreviated as the ASEAN+3). By applying statistical and econometric methods on Revealed Symmetric Comparative Advantage (RSCA) index, this paper concludes that there have been changes in the patterns of comparative advantage in the ASEAN+3. The increases in overall comparative advantage are encouraged by the higher increases in comparative advantage of groups of products that had no or lower comparative advantage in the past. The comparative advantage pattern of the ASEAN is becoming similar with that of Japan. However, there is no stationary level of similarity in the patterns of comparative advantage.
\end{abstract}

- JEL Classification : F10, F14, F17

- Key Words: comparative advantage, specialization and de-specialization, convergence

\section{Introduction}

Since the beginning of multilateral trade system, many regional trade agreements (RTAs) and regional economic integrations have been achieved, for examples the European Union (EU), the North American Free Trade Agreement (NAFTA), the Mercado Común del Sur (MERCOSUR, Southern Common Market), the Association of South East Asian Nations (ASEAN) - Free Trade Area (AFTA), etc. The achievements of RTAs and regional economic integrations, to

\footnotetext{
*Tri Widodo: Faculty of Economics and Business, Gadjah Mada University, Jl. Humaniora No. 1, Bulaksumur, Yogyakarta 55281, Indonesia, Tel: 62 (274) 548510, Fax: 62 (274) 563 212, e-mail: kociwid@yahoo.com.

@2009-Center for International Economics, Sejong Institution, Sejong University, All Rights Reserved.
} 
some extent, have brought positive as well as negative implications that might appear in the forms of trade creation and trade diversion for the member and nonmember countries (Viner, 1950; McCarthy, 2006). The East Asian region was noticeably late in proceeding to the de jure (legal) regional economic integration, even though the de facto (factual) economic integration is sometimes claimed (Fouquin et al., 2006). Remarkable trade and investment activities, especially between Japan and China, as well as Japan and the individual ASEAN countries, have increased significantly. RTAs in the East Asia did not exist until the ASEAN (only among the founding members: Indonesia, Malaysia, the Philippines, Singapore, and Thailand) reached the Preferential Trade Agreements (PTA) in 1977.

Globalization, liberalization, economic integration, bilateral and multilateral agreements have encouraged international strategic alliances conducted by countries. Trade liberalization not only offers opportunities for the export development but also carries more competitive environment in the international, regional and domestic markets. Based on data from the Direction of Trade Statistics-International Monetary Fund (DOTS-IMF, 1999; 2006), the intra-regional trade of the ASEAN+3, the EU and the NAFTA grew at 112.7 percent, 110.6 percent and 109 percent for 1995-2005, respectively. In addition, the shares of their intra-regional trade in the world exports grew at 4.3 percent, 3.3 percent and 2.5 percent for 1995-2005, respectively.

Parallel with the integration process in the world market, a critical issue on the country-specific specialization and the dynamic shifts in comparative advantage patterns emerges. Isogai et al. (2002), James and Movshuk (2003), $\mathrm{Ng}$ and Yeats (2003), Roland (2003), Hinloopen and Marrewijk (2004a; 2004d), Batra and Khan (2005), and Wörz (2005), among others, examined the issue. Whether there are systematic changes in the comparative advantage and specialization of trade in the East Asian economies or not has been a crucial issue for the future development of the East Asian economic integration. Economic theory argues that there is a relationship between the factor intensities for specific products and the location for their optimal production. Products using labor-intensive techniques in their productions should normally be produced in poorer, less developed countries where labor cost is relatively low. In contrast, products using capital-intensive techniques in their production should be produced in richer, developed countries where the cost of capital is relatively low. In other words, less developed countries should have comparative advantage in labor-intensive products; meanwhile, more 
developed countries should have comparative advantage in capital-intensive products. The East Asian region is an interesting object regarding the issue since it consists of relatively diverged economies.

This paper focuses on shifts in the patterns of comparative advantage of the ASEAN (only the five members: Singapore, Indonesia, Malaysia, Thailand and the Philippines) ${ }^{1}$ as a single entity, Japan, Republic of Korea (hereafter Korea) and the People's Republic of China, Mainland (hereafter China), which are all commonly abbreviated as the ASEAN +3 . This paper is addressed to answer some questions. First, what sorts of exported products do the ASEAN +3 have comparative advantages? Second, how far have the comparative advantages of the ASEAN+3 shifted dynamically? Third, does the ASEAN's pattern of comparative advantages follow sequentially those of Japan, China, and Korea?

The rest of this paper is organized as follows. Section II exhibits the methodology. The results and analysis are described in Section III. Finally, some conclusions are presented in Section IV.

\section{Methodology}

\section{A. Data}

This paper uses data on exports published by the United Nations (UN) namely the United Nations Commodity Trade Statistics Database (UN-COMTRADE). We employ the 3-digit Standard International Trade Classification (SITC) Revision 2 and focus on 237 groups of products. ${ }^{2}$ Two groups of products (SITC) are not covered in this research, i.e. Hoop and strip of iron or steel, hot-rolled or coldrolled (SITC 675) and Postal packages not classified according to kind (SITC 911). ${ }^{3}$

\footnotetext{
The other ASEAN countries failed to report their official trade statistics to the United Nations, or data very late and on an irregular basis. For instance, Lao PDR has never reported statistics to the United Nation-Commodity Trade Statistics (UN-COMTRADE), which is the main source of data for this paper. Vietnam stopped reporting trade statistics to the United Nations in 1989. Vietnam and Myanmar has no data in the UN-COMTRADE database. Brunei has been consistent but late reporter, for 1986-2003. Cambodia has data only for 2000-2004.

${ }^{2}$ The SITC Revision 2 is suitable for this paper since it provides appropriately the detailed groups of products as well as the range of available data.

${ }^{3}$ The two SITC have been not reported since 2001 in the world market. Technically, the Revealed Symmetric Comparative Advantage (RSCA) index, which is employed in this paper, is not defined when there is no trade in the world market. For 1976-2000, the average share of exports of the two SITC was only 0.13 percent in the world total exports.
} 


\section{B. Revealed Symmetric Comparative Advantage (RSCA)}

We apply an indicator of comparative advantage, namely Revealed Symmetric Comparative Advantage (RSCA) by Dalum et al. (1998) and Laursen (1998). The RSCA index is a simple decreasing monotonic transformation of Revealed Comparative Advantage (RCA) or Balassa index (Balassa, 1965). RCA index is formulated as follows:

$$
\mathrm{RCA}_{i j}=\left(\mathrm{x}_{i j} / \mathrm{x}_{i n}\right)\left(\mathrm{x}_{r j} / \mathrm{x}_{r n}\right)
$$

where $\mathrm{RCA}_{i j}$ represents revealed comparative advantage of country $i$ for group of products (SITC) $j$; and $\mathrm{x}_{i j}$ denotes total exports of country $i$ in group of products (SITC) $j$. Subscript $\mathrm{r}$ refers to all countries without country $i$, and subscript $\mathrm{n}$ refers to all groups of products (SITC) except group of product $j$. The values of the index vary from 0 to infinity $\left(0 \mathrm{RCA}_{i j} \leq \infty\right)$. $\mathrm{RCA}_{i j}$ greater than one means that country $i$ has comparative advantage in group of products $j$. In contrast, $\mathrm{RCA}_{i j}$ less than one implies that country $i$ has comparative disadvantage in group of products $j$.

Since $\mathrm{RCA}_{i j}$ turns out to produce values that cannot be compared on both sides of one, Dalum et al. (1998) and Laursen (1998) proposed Revealed Symmetric Comparative Advantage (RSCA) index, which is formulated as follows:

$$
\mathrm{RSCA}_{i j}=\left(\mathrm{RCA}_{i j}-1\right) /\left(\mathrm{RCA}_{i j}+1\right)
$$

The values of $\mathrm{RSCA}_{i j}$ index can vary from minus one to one (or $-1 \leq \mathrm{RSCA}_{i j} \leq 1$ ). $\mathrm{RSCA}_{i j}$ greater than zero implies that country $i$ has comparative advantage in group of products $j$. In contrast, $\operatorname{RSCA}_{i j}$ less than zero implies that country $i$ has comparative disadvantage in group of products $j$.

\section{Distribution of RSCA: Specialization or De-specialization?}

The distribution of RSCA can be used to analyze the dynamics of comparative advantage. Laursen (1998), James and Movshuk (2003), Hinloopen and Marrewijk (2001; 2004a; 2004b; 2004c), among others, examined the distribution of RCA index in related with the dynamics of comparative advantage. Some descriptive statistics -i.e. arithmetic mean, standard deviation and skewness- are applied to examine the shift in comparative advantages in the ASEAN, Japan, Korea and China. Those statistics of RSCA for the ASEAN, Japan, Korea and China are 
calculated over time. One might argue that median could be better measurement of central tendency than the mean since the distribution are non-symmetric (skewed) distribution (McClave et al., 2001; Hinloopen and Marrewijk, 2001). Standard deviation is used to examine the dispersion of revealed comparative advantages. Positive value of skewness coefficient of RSCA for a specific country and a specific year indicates that the country is more concentrated on products with low comparative advantage. In contrast, negative value skewness coefficient of RSCA for a specific country and a specific year implies that the country is more concentrated on products with high comparative advantage. By looking at the values of skewness coefficient over time, we can analyze the direction of specialization or the shift in comparative advantages.

We might make a hypothesis that the ASEAN, Japan, Korea or China have more de-specialized and more concentrated on products with higher comparative advantage over periods of observation (shown by higher value of mean or median; smaller standard deviation and smaller value of skewness over time) as presented in Figure 1.

\section{The Spearman's Rank Correlation: Complement or Substitution?}

To examine the shifts in the patterns of comparative advantages, we apply rank correlation analysis. Correlations (Pearson's correlation, Spearman's rho, and Kendall's tau-b) measure how variables or rank orders are related. Pearson's

Figure 1. Hypothetical Shifts in Comparative Advantage

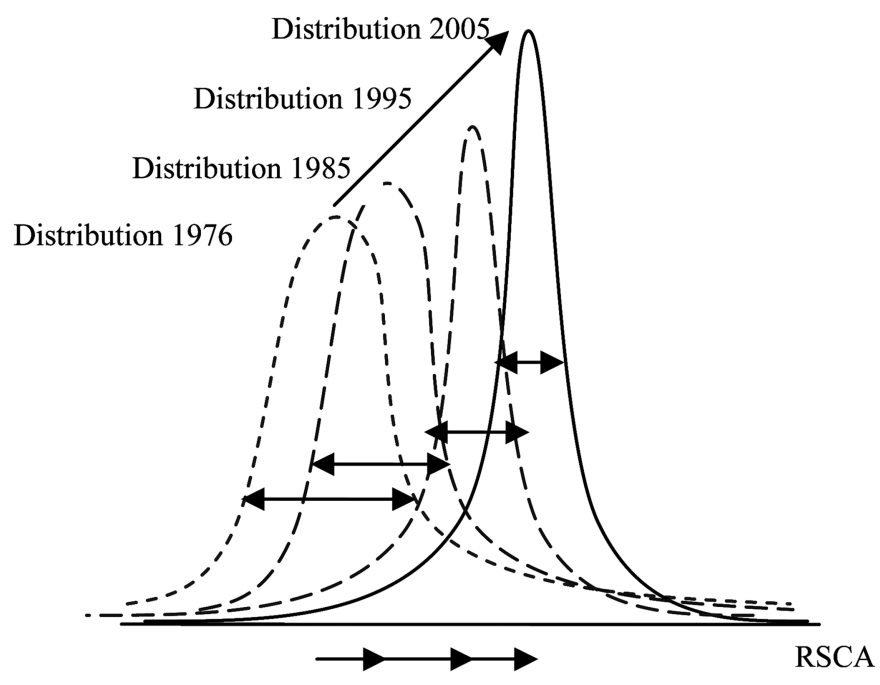


correlation coefficient is a measure of linear relationship. If the relationship is not linear, Pearson's correlation coefficient is not an appropriate statistic for measuring the relationship. Since we want to analyze the changes in patterns or in structures (rank orders) of comparative advantage, we employ the Spearman's rank correlation. ${ }^{4}$ It measures the closeness of the relationship the two sets of rankings that is, between the rankings of the one variable and the rankings of the other variable (in our case: RSCA across periods and RSCA across countries). For example, based on RSCA index, the group of products SITC 001 has the $1^{\text {st }}$ rank in 1995 becoming the $5^{\text {th }}$ rank in 2005 , the group of product SITC 002 has the $237^{\text {th }}$ rank in 1995 becoming the $2^{\text {nd }}$ rank in 2005, and so on. Hence, the degree of association between rank orders of RSCA (across periods and across countries) can be compared by looking at the Spearman's rank correlation coefficients, which are formulated as follows (Leu, 1998; James and Movshuk, 2003):

- Across periods (years):

$$
\rho_{s, C t_{a}, C t_{b}}=1-6\left[\frac{\sum_{i=1}^{n} d_{R_{j}}^{2}}{n\left(n^{2}-1\right)}\right]
$$

- Across countries:

$$
\rho_{s, C t_{a}, I t_{b}}=1-6\left[\frac{\sum_{i=1}^{n} d_{R_{j}}^{2}}{n\left(n^{2}-1\right)}\right]
$$

where:

$\rho_{s, C t_{a}, C t_{b}}=$ the Spearman's rank correlation coefficient between country C's RSCA at time $t_{a}$ (symbol: $C t_{a}$ ) and country C's RSCA at time $t_{b}$ (symbol: $C t_{b}$ ).

$\rho_{s, C t_{a}, I t_{b}}=$ the Spearman's rank correlation coefficient between country C's RSCA at time $t_{a}$ (symbol: $C t_{a}$ ) and country I's RSCA at time $t_{\mathrm{b}}$ (symbol: $I t_{b}$ ). $d_{R_{j}}^{2}=\left(R_{\mathrm{RSCA}_{j C, t_{a}}}-R_{\mathrm{RSCA}_{j C, t_{b}}}\right)^{2}$ for across periods (years).

\footnotetext{
${ }^{4}$ The rank correlation coefficient is often applied instead of the ordinary correlation coefficient when variables are far from normally distributed (Mansfield, 1994:506). By employing Kolmogorov-Smirnov test, we reject the null hypothesis of normal distribution of almost all the RSCA indexes of the ASEAN, Japan, Korea and China for the periods of observation. Far departures of normality have no effect on the inferential statistics (hypothesis test) of the rank correlation coefficient, since it does not assume normality of distribution.
} 
$d_{R_{j}}^{2}=\left(R_{\mathrm{RSCA}_{j C, t_{a}}}-R_{\mathrm{RSCA}_{j c, t_{b}}}\right)^{2}$ for across countries.

$R_{\mathrm{RSCA}_{j C, t_{a}}}=$ the rank of country C's RSCA of group of products $j$ at time $t_{a}$

$R_{\mathrm{RSCA}_{j C, t_{b}}}=$ the rank of country C's RSCA of group of products $j$ at time $t_{b}$

$R_{\mathrm{RSCA}_{j l, t_{b}}}=$ the rank of country I's RSCA of group of products $j$ at time $t_{b}$

$\mathrm{n}$ is number of observation groups of products (i.e. 237 SITC)

$t_{a}$ and $t_{b}$ are times (years)

The values of Spearman's rank correlation coefficients can vary from minus one (a perfect negative relationship in rank orders) and one (a perfect positive relationship in rank orders). A value of zero indicates no relationship in rank orders. Within a specific country, it is applied across periods to analyze the dynamic shift in patterns (rank orders) of comparative advantage. If the correlation is closer to one (1), the shift in patterns (rank orders) of comparative advantage is less significant. For the extreme case, the coefficient equals one (1), when the rank orders of RSCA of the two periods of observation are the same, there is no change in the rank orders at all. If it is closer to minus one (-1), the shift in patterns (rank orders) of comparative advantage is more significant. For the extreme case, the coefficient equals minus one (-1), when the rank orders of RSCA of the two periods of observation are completely in the reverse orders.

The Spearman's rank correlation is also applied for across countries i.e. the ASEAN, Japan, Korea and China to investigate the association of the patterns (rank orders) of comparative advantage. Higher and positive value of Spearman's correlation coefficient indicates stronger competition between two countries in the export market, since their patterns of comparative advantage become similar. In contrast, smaller and negative value of Spearman's rank coefficient implies stronger complementary of these two counties in supplying products to the export market, since their patterns of comparative advantage become dissimilar.

\section{E. Stationary Level of Similarity in the Patterns of Comparative Advantage}

This paper applies a stationary test, namely Augmented Dickey-Fuller (ADF), on the Spearman's rank correlation series to investigate the existence of steady state or stationary ${ }^{5}$ level of similarity in the patterns of comparative advantage. The ADF test constructs a parametric correction of the typical Dickey-Fuller test for highest-order correlation by assuming that the series (in this paper the Spearman's rank correlation coefficients, $\rho$ ) follows autoregressive with order $p$-denoted as AR $(p)$ - process and adding lagged difference terms of the dependent variable $\rho_{t}$ to the 
right hand side (Enders, 1995; Gujarati, 1995). The general equation of the ADF is formulated as follows:

$$
\Delta \rho_{t}=\beta_{\mathrm{o}}+\beta_{1} \rho_{t+1}+\sum_{i=1}^{p} \alpha_{\mathrm{i}} \Delta \rho_{t-i}+\delta t+\varepsilon_{t}
$$

where $t$ and $\varepsilon_{t}$ are time and the error terms, respectively. The $\rho_{t}$ is non-stationary if we accept the hypothesis $\left(\mathrm{H}_{\mathrm{o}}\right)$ saying that $\beta_{1}=0$, which implies that there is no steady-state or stationary level of similarities in the patterns of comparative advantage. In contrast, the $\rho_{t}$ is stationary if we reject the hypothesis $\left(\mathrm{H}_{\mathrm{o}}\right)$ saying that $\beta_{1}=0$, which indicates the existence of stationary level of similarities in the patterns of comparative advantage. For testing the hypothesis, we follow conventional Student's $t$-distribution $t_{\beta_{1}}=\frac{\beta_{1}}{\operatorname{se}\left(\beta_{1}\right)}$ and it is compared with
MacKinnon (1996) critical value.

\section{Results and Analysis}

\section{A. Trends in Overall Comparative Advantage}

Figure 2 shows the trends in overall median ${ }^{6}$ of the Revealed Symmetric Comparative Advantage (RSCA) index for the ASEAN, Japan, Korea and China (in Panel a) and 5 individual countries of the ASEAN (in Panel b) for 1976-2005. It is clearly shown that the changes in comparative advantage of ASEAN +3 in the periods 'before 1990' were more significant than the periods 'after 1990'. Japan as the leader in the 'flying geese' (FG) formation ${ }^{7}$ had relatively high comparative advantage until the late 1970s. However, Japan had a downward trend in

\footnotetext{
${ }^{5}$ Mathematically, a steady-state or stationary value is defined as the value of a variable, let say $y$, at which the system comes to rest (Hoy et al., 1996:646). This implies that $y_{t+1}=y_{t}$. For example, in the linear, firstorder, autonomous difference equation $y_{t+1}=a y_{t}+b$, where $\mathrm{a}$ and $\mathrm{b}$ are known constants, the stationary value is $\overline{\mathrm{y}}=\frac{\mathrm{b}}{(1-\mathrm{a})}$. It is clear that there will be no steady-state or stationary value if $a=1$; in contrast, there will be a stationary value if $a \neq 1$. In this difference equation, $y_{t}$ converges to it its stationary value if only if $|a|<1$. Now, let us consider the unit root test for the following model: $y_{t}=\rho y_{t-1}+u_{t}$, where $\mathrm{u}_{\mathrm{t}}$ is error terms. If the coefficient $\rho$ is equal to $1(\rho=1)$, we face what is known as the unit root problem, i.e. a nonstationary situation. In contrast, if $\rho$ is not equal to $1(\rho \neq 1)$, the series $y_{t}$ is stationary one. In econometrics, "a series is said to be stationary if its mean and variance are constant $\left(\mathrm{E}\left[y_{t}\right]=\mu, \operatorname{var}\left(y_{t}\right)=\mathrm{E}\left[y_{t}-\mu\right]^{2}=\sigma^{2}\right)$ and the value of covariance between two time periods depends only on the distance of lag between the two time periods and not on the actual time at which the covariance computed $\left(\gamma_{k}=\mathrm{E}\left[\left(y_{t}-\mu\right)\left(y_{t+k^{-}}-\mu\right)\right]\right)$ )" (Gujarati, 1995:713).

${ }^{6}$ Since the distribution of RSCA is skewed one, the median is better measurement of central tendency than the mean.
} 
comparative advantage for 1976-1995. The strong reason for this decrease is the foreign direct investment (FDI) by Japan. There was a slight increase in comparative advantage in 1996 but then followed by the decrease in comparative advantage during the Asian financial crisis 1997-1998. Since then, there has been an upward trend in comparative advantage. There were 153 SITC with decrease in their comparative advantage for 1976-1995. Meanwhile, during 1998-2005 there were 170 SITC with increase in their comparative advantage.

The ASEAN had a significant upward trend in comparative advantage for 19761989. The SITC 634 (Veneers, plywood, improved" wood and other wood worked nes"), 075 (Spices), 846 (Under-garments, knitted or crocheted), 424 (Other fixed vegetable oils, fluid or solid, crude, refined), 074 (Tea and mate), 899 (Other miscellaneous manufactured articles, nes), 247 (Other wood in the rough or roughly squared), 842 (Men's and boys' outerwear, textile fabrics not knitted or crocheted), 431 (Animal and vegetable oils and fats, processed, and waxes), 848 (Articles of apparel, clothing accessories, non-textile, headgear), among others, had contributed the positive growth of comparative advantage. The comparative

Figure 2. Trends in Overall Median of Comparative Advantages, 1976-2005

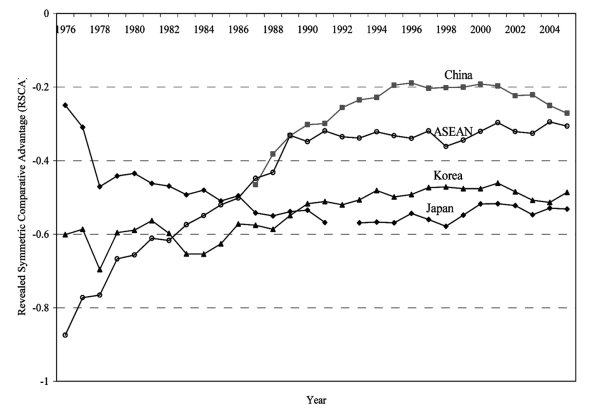

(a) the ASEAN+3

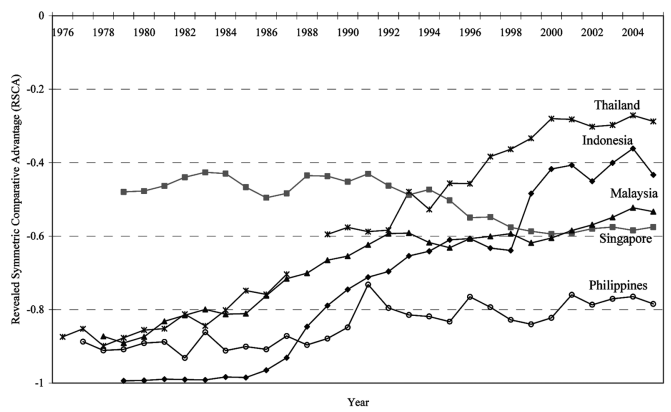

(b) Five Countries of the ASEAN

Note: there is no data for Japan in 1992 and Thailand in 1988.

Source: UN-COMTRADE, author's calculation.

\footnotetext{
${ }^{7}$ The 'flying geese' paradigm was introduced by Kaname Akamatsu in the 1930s in the several articles available only in Japanese. Kaname Akamatsu showed himself in the world academia after the World War II in the two articles $(1961,1962)$ in English. 'Flying geese' model intends to explain the catching-up process of industrialization of latecomer economies from intra-industry, inter-industry and international aspects. It might be argued that the structural transformation of industrialization in East Asia follows this 'flying geese' formation. Garment, Steel, Popular TV, Video and HDTV are frequently used to illustrate the formation. Those products have been transferred from Japan to Newly Industrialized Economies (NIEs: Hog Kong, Taiwan, Singapore and Korea); from NIEs to the ASEAN4 (Malaysia, Indonesia, Thailand and the Philippines); from the ASEAN4 to latecomer economies.
} 
advantage decreased slightly during 1992-1997, but it has increased slowly since 1998. It seems that the Asian economic crisis has brought positive impacts on increasing the ASEAN's comparative advantages. Depreciation of the ASEAN countries' currencies encouraged exports and discouraged imports. Elliot and Ikemoto (2004) examined the ASEAN intra- and extra-regional bias in bilateral trade flows and how these relationships have altered over time. They found that one effect of the Asian economic crisis was to generate a stronger desire to source imports from within the region.

The trend in comparative advantage of the ASEAN after 1990 is quiet similar with that of Japan. Elliot and Ikemoto (2004) found that trade flows of the ASEAN were not significantly affected in the years immediately following the signing of the AFTA agreement. It might be argued that the openness and the dominance of the East Asian countries, especially Japan as pivotal trading partner, to some extent affected the ASEAN comparative advantage. Data from DOTS-IMF $(1998 ; 2006)$ shows the ASEAN exports going to the intra-regional trade, Japan, China, Hong Kong, Taiwan, Korea covered 24.5 percent 13.1 percent, 5 percent, 6 percent, 3.6 percent and 3.6 percent, respectively. The argument of interrelated activities between the ASEAN and Japan applies. Japan imports materials (raw or semimanufactured) from the ASEAN, then processes them with higher technology, and finally exports the final products to the ASEAN and rest of the world.

In Figure 2, Panel (b) exhibits trends of comparative advantage in each individual countries of the ASEAN. Since 1978, Thailand has an upward trend in comparative advantage. Indonesia has also an upward trend in comparative advantage since 1982. After the end of the World War II, the industrial and trade policies in the ASEAN countries might be distinguished into three stages. First, the ASEAN countries implemented import-substitution policies with very high protection. Second, due to lack of government financial support and crisis of the balance of trade, the policies were replaced by more export-oriented policies, which were generally quite effective in increasing economic growth and stimulating industrialization. Masuyama (1997) noted that the policies faced, at least, three challenges in pushing further liberalization i.e. the need to attract more foreign direct investment (FDI), the competition with other countries in the North American and European markets, and the necessity of more decentralized and market-oriented decision making. Third, realizing these challenges, the East Asian countries pursued more market-oriented policies, not only in industrial and trade policies but also in macroeconomic (fiscal and monetary) ones. 
China had significant increases in comparative advantage for 1987-1993. However, the increases became relatively insignificant for 1993-2000 and China has a downward trend in comparative advantage since 2000. The decrease of average comparative advantage has been caused by the exports diversifications. In the early stage of liberalization, it is common for countries to exploit their traditional exported products. In the case of China, traditional products with high comparative advantage in 1985 were silk, explosive and pyrotechnic products, crude animal materials, tea and mate, vegetable textile fibres, cotton, vegetables and tin, among others. Moving from exporting resource-based products such as agricultural products to exporting standardized manufactured-products has decreased the comparative advantage. The domestic structural changes of exports (diversification) have lowered the comparative advantage of traditional exported products; meanwhile, the new exported products have still no comparative advantages in the international market yet.

\section{B. De-specialization}

International trade theory suggests that country will exploit their products, which have comparative advantage, and then it becomes specialized on those products. The comparative advantage of those products becomes higher and higher, meanwhile the other products will relatively have smaller increases, stagnant or even decreases in comparative advantage. If it is case, there must be larger difference (dispersion) in comparative advantages among products. Statistically, this will be shown by the larger standard deviation of the comparative advantages. Figure 3 exhibits trends in mean, median, standard deviation and skewness of RSCA of the ASEAN, Japan, China and Korea. Some general patterns of comparative advantage can be noted. First, except Japan in 1976, all countries have a concentration on the products with low comparative advantages (shown by positive value of skewness coefficient). However, the concentration become on the products with higher comparative advantage over time (shown by decreasing value of skewness).

Second, the difference in comparative advantages among products tends gradually to be smaller and smaller over time (shown by decreased values of standard deviation) for the ASEAN, Japan, China and Korea. In other words, all countries exhibit de-specialization. The increase in the mean (or median) followed by the decrease in the standard deviation of RSCA implies that the increase of overall comparative advantage might be encouraged by the higher increase in 
Figure 3. Trends in Mean, Median, Standard Deviation and Skewness of Comparative Advantages, 1976-2005

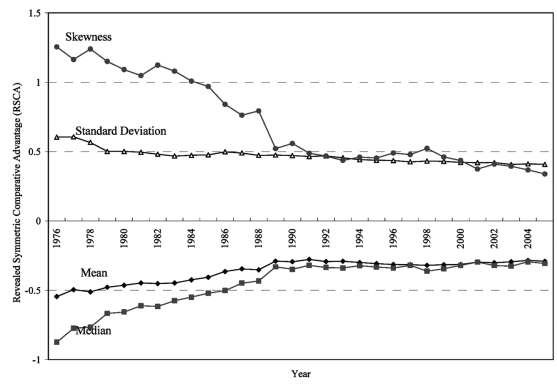

(a) the ASEAN

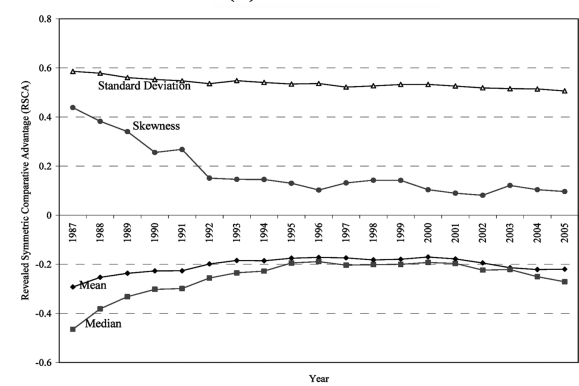

(a) China

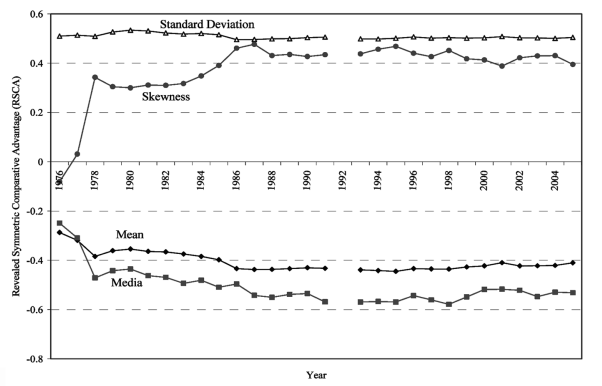

(b) Japan

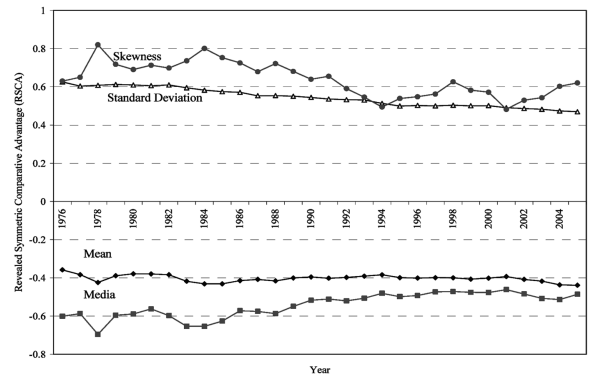

(b) Korea

Note: there is no data for Japan in 1992.

Source: UN-COMTRADE, author's calculation.

comparative advantage of products that had no or lower comparative advantage in the past.

In Figure 4, Panels (a)-(h) exhibit the trends of comparative advantages of the broad product groups i.e. Foods and feeds; Agricultural materials; Mineral fuels; Ores, minerals and metals; Chemicals; Machinery and transport; Other manufactures; and Miscellaneous manufactured goods. ${ }^{8}$ In general, it is clearly shown that China and the ASEAN, as well as Korea and Japan, had similar trends in their comparative advantages. Almost in all the product groups, China had relatively higher comparative advantage except in Machinery and transport. China and the ASEAN had relatively much higher comparative advantages in natural resources based products i.e. Foods and feeds; Agricultural materials and Mineral fuels than those of Korea and Japan. However, the three product groups exhibited

\footnotetext{
${ }^{8}$ This broad product classification follows $\mathrm{Ng}$ and Yeats (2003). The products are classified by SITC Revision 2 as Foods and feeds (SITC 0+1+22+4); Agricultural materials (SITC 2-22-27-28); Mineral fuels (SITC 3); Ores, minerals and metals (SITC 27+28+67+68); Chemicals (SITC 5); Machinery and transport (SITC 7); Other manufactures (SITC 6-67-68+84); and Miscellaneous manufactured goods (SITC 8-84).
} 
Figure 4. Trends in Sectoral Average Comparative Advantages, 1976-2005

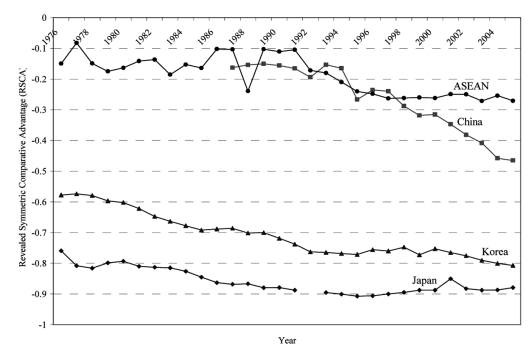

(a) Foods and Feeds

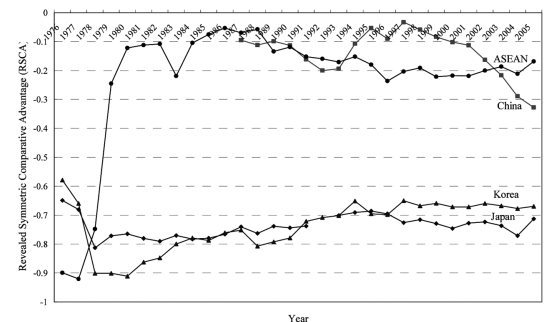

(c) Mineral Fuels

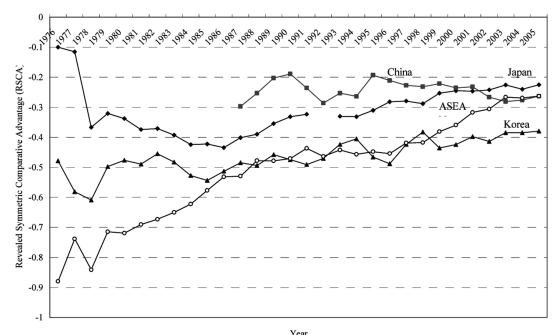

(e) Chemicals

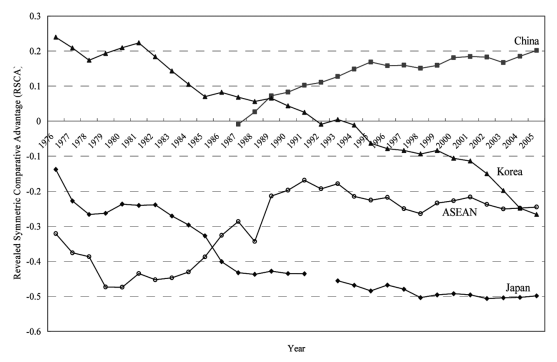

(g) Other Manufactures

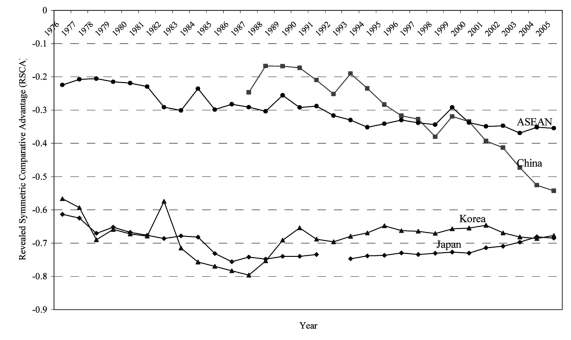

(b) Agricultural Materials

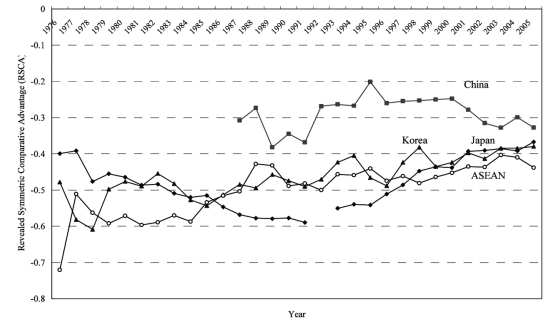

(d) Ores, Minerals and Metals

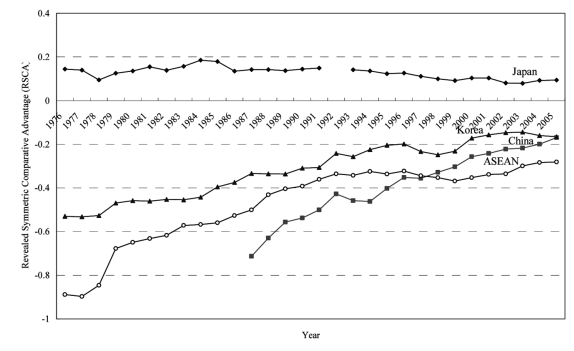

(f) Machinery and Transport

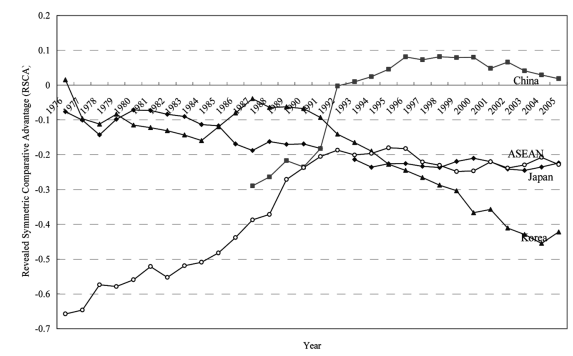

(h) Miscellaneous Manufactured Goods

Note: there is no data for Japan in 1992.

Source: UN-COMTRADE, author's calculation.

downward trends in their comparative advantage. The similar positive trends in comparative advantage for the ASEAN, Japan and Korea have happened in Ores and metal; Chemical; and Machinery and transport since the early 1980s. 
For all the ASEAN, Japan, Korea and China, we can say that the increases in comparative advantage have been mainly encouraged by de-specialization. We can see clearly by analyzing further in the sectoral (product groups) level. In the case of the ASEAN and China, the decreases in comparative advantages of Food and feeds; Agricultural materials; Mineral fuels, which had very high comparative advantage in the past, have been covered by the increases in comparative advantages of Chemical; and Transport and machinery. In the case of Japan and Korea, the decreases in comparative advantages of Other Manufacture; and Miscellaneous manufacture, which had relatively high comparative advantage in the past, have been covered by the increases in comparative advantages of Mineral and fuels; Ores and Metals; Chemicals; transports and equipment.

\section{Shifts in the Patterns of Comparative Advantage}

We calculate Spearman's rank correlations RSCA across periods (years) i.e. 1976, 1985, 1995 and 2005 to scrutinize separately the structural changes (rank orders) of comparative advantages in the ASEAN, Japan, Korea, and China. Table 1 shows Spearman's rank correlation coefficients that are all statistically significant at 1 percent level of significance ${ }^{9}$ (For comparison purposes, we present the Pearson's linear correlations in Table 2, which give similar general conclusions). The ASEAN, Japan, Korea, and China have performed the changes in the patterns (rank orders) of comparative advantages in the different levels. It is clearly shown that the ASEAN had smaller coefficients of the Spearman's rank correlation than those of Japan, Korea and China. It means that there were more dynamic changes in the patterns (rank orders) of comparative advantages in the ASEAN than in Japan, Korea or China. Japan had the slowest changes in the patterns (rank orders) of comparative advantages.

All countries exhibit slower rate of change in the patterns (rank orders) of comparative advantage. For example, the ASEAN had the coefficients of 0.54 for 1976-1985; 0.76 for 1985-1995 and 0.83 for 1995-2005. Japan had the coefficients 0.92 for 1976-1985, 0.92 for 1985-1995, and 0.95 for 1995-2005. It indicates that in the particular stage of economic development the structural change in

${ }^{9}$ The null and alternative hypotheses are $\mathrm{H}_{0}: \rho_{s, C t_{\omega} C t_{b}}=0$, and $\mathrm{H}_{0}: \rho_{s, C t_{a}, C t_{b}} \neq 0$, respectively. The test statistics is $t_{s}=\frac{\rho_{s, C t_{a}, C t_{b}}}{\sqrt{\left(1-\rho_{a, C t_{a}, C t_{b}}^{2}\right)(\mathrm{n}-2)}}$, which is distributed following the $t$ distribution with (n-2) degrees of freedom, where $\mathrm{n}$ is the number of observations (in our case, $\mathrm{n}=237$ ). The decision rule: "reject the null hypothesis if $t_{s}<-t_{\alpha / 2}$ or $t_{s}>t_{\alpha / 2}$, where $\alpha$ is the level of significance". 
Table 1. Spearman's Rank Correlation Coefficients across Periods

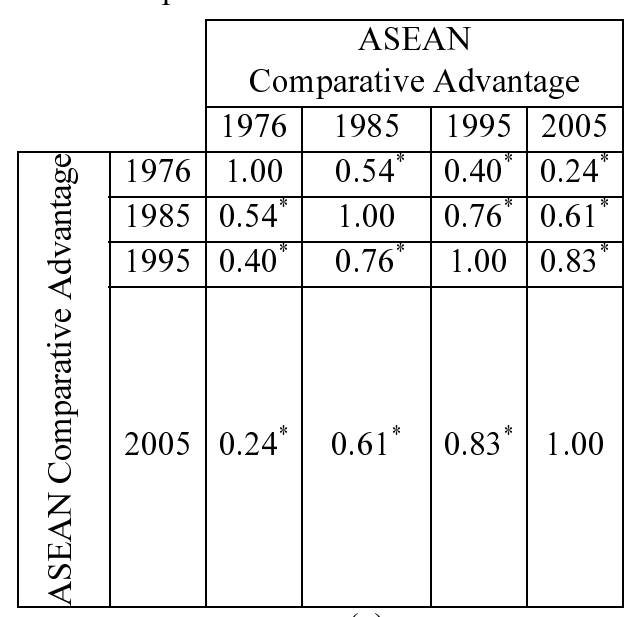

(a)

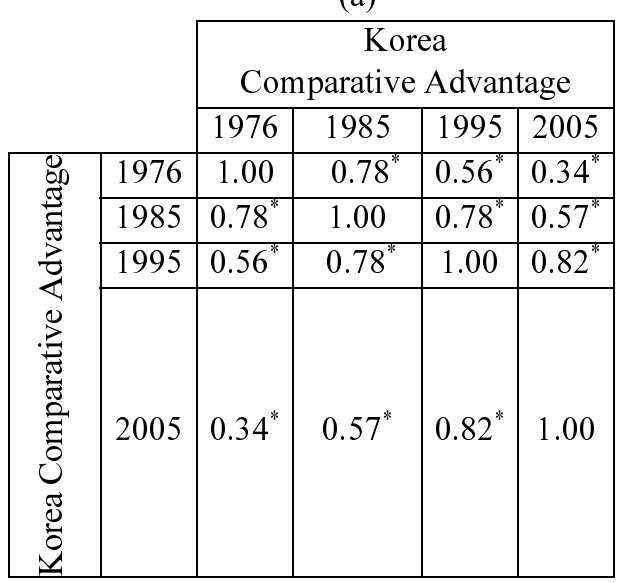

(c)

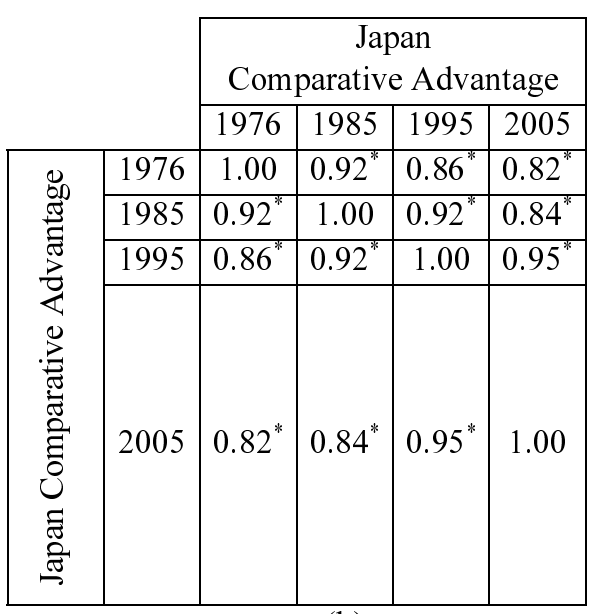

(b)

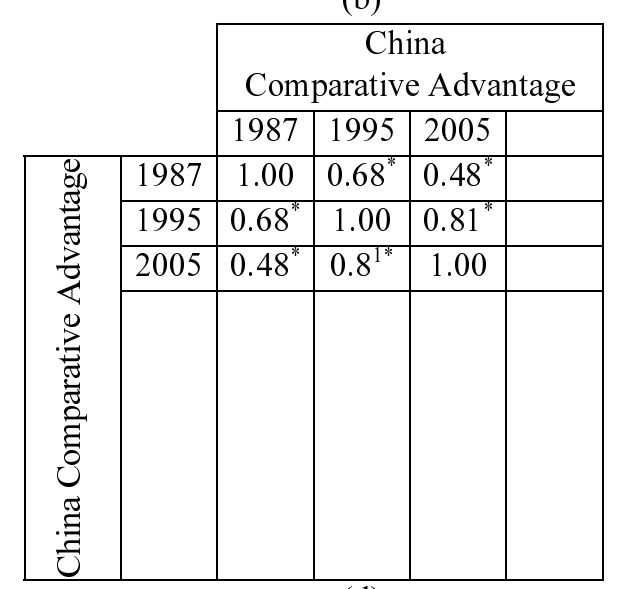

(d)

Note: * significant at 1 percent level of significance Source: UN-COMTRADE, author's calculation.

comparative advantage becomes less likely. Hollis Chenery's patterns of development approach gives the empirical analysis of the "sequential process" through which the economic, industrial and institutional structure of an underdeveloped economy is transformed over time to permit new industries to replace traditional agriculture as the engine of economic growth (Todaro and Smith, 2006). That might the case of the ASEAN. Products of manufacture have replaced traditional (agricultural and natural resource based) products, which have high comparative advantages. The transformation from agriculture to manufacture has been spurred by direct foreign investment. After manufactured products, what is next? That is the case of Japan. Manufacture products can be classified based on 
Table 2. Pearson's Correlation Coefficients across Periods

\begin{tabular}{|c|c|c|c|c|c|}
\hline & \multicolumn{4}{|c|}{$\begin{array}{c}\text { ASEAN } \\
\text { Comparative Advantage }\end{array}$} \\
\hline & & 1976 & 1985 & 1995 & 2005 \\
\hline \multirow{4}{*}{ 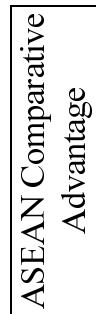 } & 1976 & 1.00 & $0.58^{*}$ & $0.35^{*}$ & $0.22^{*}$ \\
\hline & 1985 & $0.58^{*}$ & 1.00 & $0.78^{*}$ & $0.65^{*}$ \\
\hline & 1995 & $0.35^{*}$ & $0.78^{*}$ & 1.00 & $0.86^{*}$ \\
\hline & 2005 & $0.22^{*}$ & $0.65^{*}$ & $0.86^{*}$ & 1.00 \\
\hline
\end{tabular}

(a)

\begin{tabular}{|c|c|c|c|c|c|}
\hline & \multicolumn{4}{|c|}{$\begin{array}{c}\text { Korea } \\
\text { Comparative Advantage }\end{array}$} \\
\hline & & 1976 & 1985 & 1995 & 2005 \\
\hline \multirow{4}{*}{ 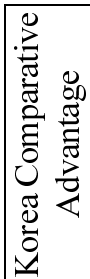 } & 1976 & 1.00 & $0.77^{*}$ & $0.51^{*}$ & $0.24^{*}$ \\
\hline & 1985 & $0.77^{*}$ & 1.00 & $0.74^{*}$ & $0.45^{*}$ \\
\hline & 1995 & $0.51^{*}$ & $0.74 *$ & 1.00 & $0.78^{*}$ \\
\hline & 2005 & $0.24^{*}$ & $0.45^{*}$ & $0.78^{*}$ & 1.00 \\
\hline
\end{tabular}

(c)

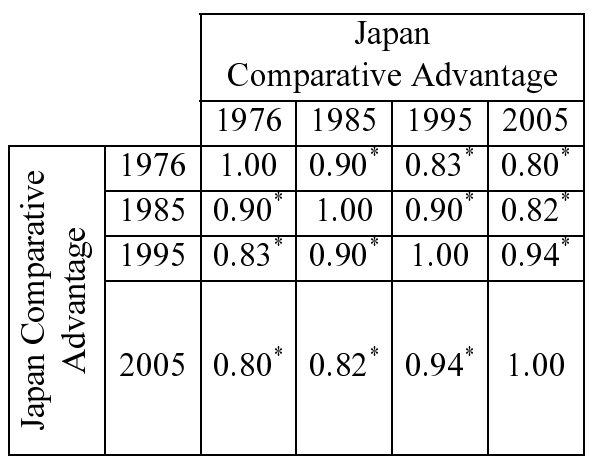

(b)

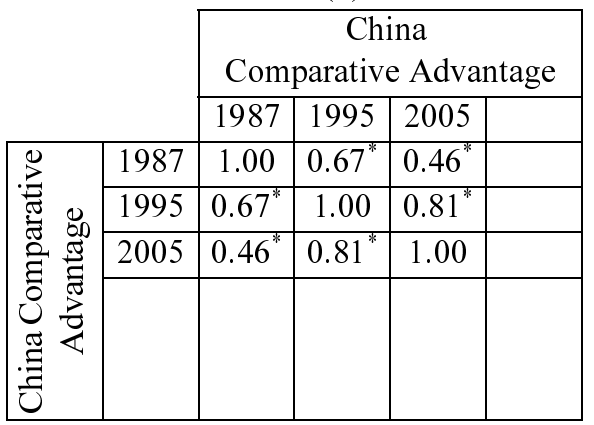

(d)

Note: * significant at 1 percent level of significance

Source: UN-COMTRADE, author's calculation.

the technological contents. During the period 1967-1983, Japan shifted its specialization from unskilled labor-intensive products to human capital and research development-intensive products (Balassa and Noland, 1989). In this stage, the significant changes in the patterns of comparative advantage is less likely to happen.

\section{Trends in Similarity of the Patterns of Comparative Advantage}

Figure 5 exhibits the trends of the Spearman's rank correlation coefficients between the ASEAN's RSCA index and Japan's RSCA index, Korea's RSCA index as well as China's RSCA index. The coefficients the ASEAN-China and the ASEAN-Korea are positive during the periods of observation. They vary from around 0.17 to 0.37 and are statistically significant different from zero. In the case of the ASEAN-Japan, up to 1994 the coefficients are still negative. This implies a complement relationship in the patterns of comparative advantage. Sharp decreases in the correlation coefficient in the late 1970-s are mainly caused by the increase of 
Figure 5. Trends in Spearman's Rank Correlation Coefficients of the ASEAN +3

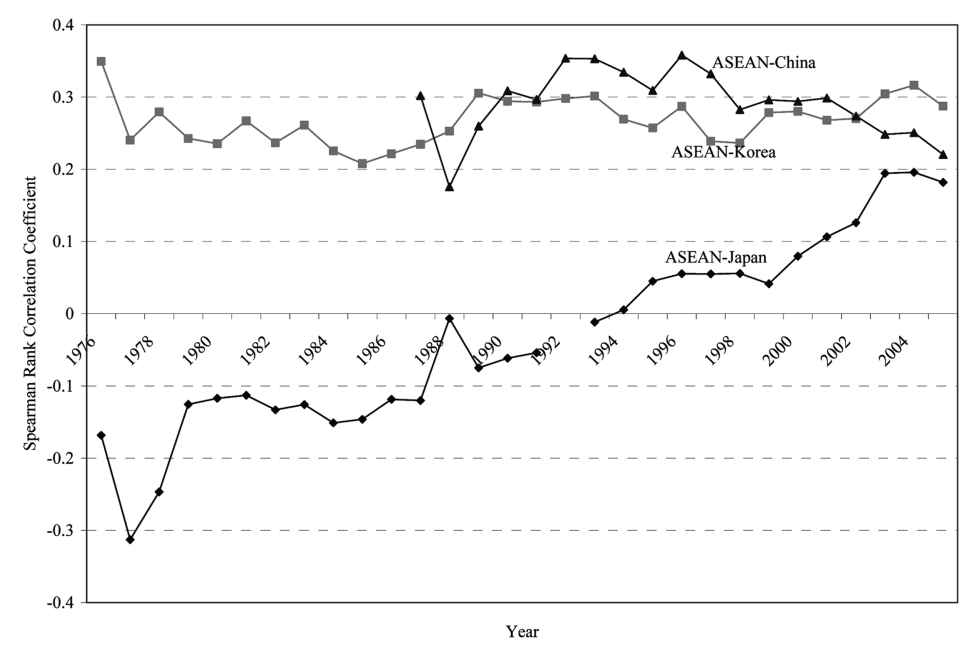

oil-price ("oil-boom") in the international market. However, since 1995 the coefficient has become positive and approached 0.2 (statistically significant different from zero) in 2003.

The pattern of comparative advantage of the ASEAN has become similar with that of Japan. There some reasons for this phenomenon. First, the ASEAN has missed its comparative advantage in the traditional (agriculture, natural resource based) groups of products. The SITC 264 (Jute, other textile bast fibres, nes, raw, processed but not spun), 034 (Fish, fresh, chilled or frozen), 081 (Feeding stuff for animals (not including unmilled cereals)), 044 (Maize, unmilled), 261 (Silk), 291 (Crude animal materials, nes), 121 (Tobacco unmanufactured; tobacco refuse), 683 (Nickel), and 046 (Meal and flour of wheat and flour of meslin), among others, are SITC with decreases in their comparative advantage for 1980-2005. There were 35 groups of products - dominated by 1-digit SITC heading 0 and 2- with decreases in comparative advantage for 1980-2005.

Second, the main potential reason for this is about the Japanese foreign direct investment (FDI), especially going to the ASEAN countries. Following the "flying geese" formation, Japanese companies have invested heavily in the region since 1960s. Balassa and Noland (1989) found that during the period 1967-1983 Japan's pattern of specialization in manufactures changed dramatically from specialization in unskilled labor-intensive goods to human capital and research development intensive products. The industries were allocated to the ASEAN countries. There are two types of Japan's FDI i.e. "pro-trade-oriented" and "anti-trade-oriented". 
Kojima (1995) found that Japanese investment in East Asian economies also expanded and was generally of the pro-traded-oriented type.

Third, to some extent, Japan has lost its export comparative advantage due to its foreign investment direct in the advanced economies. Kojima (1995) found that there was a large shift of Japan's FDI toward the advanced economies in the 1980s that was generally not of the pro-traded-oriented type but rather of the anti-tradeoriented one. When Japan did foreign direct investment in advanced economies, Japanese exports for the related products to the advanced countries decreased consequently due to change in the comparative advantage. Theoretically, when the composition of inferior and superior industries related with labor productivity differs between countries then trade is promoted between these complementary partners. The degree of complementarities of comparative advantage between Japan and its export partners has been declining, and has led to the stagnation of Japanese exports after the 1990s. Balassa and Noland (1989) found that Japan and the United States had similar in their comparative advantage i.e. human capital, and research and development products.

Japanese products, capital and intermediate goods, which had high comparative advantage and very competitive internationally for a long time, have lost their comparative advantage. The markets have been taken over by the countries, including the ASEAN, where Japan's (pro-trade-oriented) investment has greatly allocated. Meanwhile, the complementarities of comparative advantage between Japan and the advanced countries declined due to Japan's (anti-trade-oriented) foreign direct investment. Those have spurred the caching-up of the ASEAN's pattern of comparative advantage with that of Japan.

\section{E. No Steady-state in the Similarity of Patterns: Dynamic Comparative Advantage}

An interesting issue regarding the similarity in the patterns of comparative advantage between the ASEAN and Japan; the ASEAN and China; as well as the ASEAN and Korea is whether a steady-state or stationary level of the similarity exists or not. In other words, do they have a certain level of similarity in the patterns of comparative advantage? It might be hunched that there will be, to some extent, similarity (convergence) in the patterns of comparative advantage. Theoretically, specialization based on comparative advantage under free trade determines the (endogenous) rate of productivity growth in sectors in the economies. Productivity levels determine comparative advantage and affect the 
Table 3. Stationary Test on Spearman's rank Correlation Coefficients across Countries

\begin{tabular}{ccccc}
\hline $\begin{array}{c}\text { Patterns of Com- } \\
\text { parative Advantage }\end{array}$ & $\begin{array}{c}\text { ADF Test Sta- Level of Signifi- } \\
\text { tistic }\end{array}$ & $\begin{array}{c}\text { Critical Value } \\
\text { cance }\end{array}$ & Conclusions \\
\hline \multirow{2}{*}{ ASEAN-Japan } & -3.11 & $5 \%$ & -4.37 & Non-stationary \\
& & $10 \%$ & -3.60 & Non-stationary \\
& & & -3.24 & Non-stationary \\
& & $1 \%$ & -4.36 & Non-stationary \\
ASEAN-Korea & -2.36 & $5 \%$ & -3.59 & Non-stationary \\
& & $10 \%$ & -3.23 & Non-stationary \\
& & $1 \%$ & -4.73 & Non-stationary \\
ASEAN-China & -2.80 & $5 \%$ & -3.76 & Non-stationary \\
& & $10 \%$ & -3.32 & Non-stationary \\
\hline
\end{tabular}

Source: UN-COMTRADE, author's calculation.

allocation of labor (resources). This sequentially determines relative rates of productivity growth, and thereby feeds back to shape the evolution of productivity levels over time. In this way, current comparative advantage is endogenously determined. The inclusion of comparative advantage in models of growth and trade has led a number of authors to speak in term of 'dynamic comparative advantage' (Nelson, 1977; Proudman and Redding, 2000; Redding, 2002; Barnes et al., 2004; among others). From Figure 5, for example, the Spearman's rank correlation coefficients of the patterns (rank orders) of comparative advantage between the ASEAN and Korea were fluctuated around 0.2-0.3. Could we say that there will be a stationary level of similarity in the patterns of comparative advantage between the ASEAN and Korea? In contrast, the correlation coefficients between ASEAN and Japan exhibited upward trend overtime. Could we say that there will be no stationary level of similarity in the patterns of comparative advantage between the ASEAN and Japan?

Table 3 shows the results of Augmented Dickey-Fuller (ADF) stationary tests on the series of Spearman's rank correlation coefficients between the ASEAN's RSCA index and Japan's RSCA index, Korea's RSCA index, as well as China's RSCA index. Since the ADF test statistic greater (or less in the absolute value) than the chosen critical values (with the levels of significance of 1 percent, 5 percent, and 10 percent), we accept the hypothesis $\left(\mathrm{H}_{\mathrm{o}}\right)$ saying that series of Spearman's rank correlation coefficients (ASEAN-Japan; ASEAN-Korea and ASEAN-China) are non-stationary ones. In other words, our data indicates that there is no steady-state 
or stationary level of similarity in the patterns of comparative advantage of the ASEAN-Japan, the ASEAN-Korea, and the ASEAN-China.

If we only believe on the traditional static comparative advantage (based on factors endowment - Heckscher-Ohlin theory), it might not be beneficial situation for the ASEAN+3 economic integration since the similar direction in the patterns of comparative advantage also indicates competition (substitution). However, we would argue that the similarity in the patterns of comparative advantage is only the necessary condition for the existence of competition (substitution) relationships. There are still sufficient conditions for it, such as similarities in country size, level of economic development, products, inputs, technology, etc. In fact, there are differences in the catch-up processes and the stage of economic development in the ASEAN +3 region as the flying geese paradigm recognizes. Through Japanese (pro-trade-oriented) foreign direct investment expansion, the patterns of comparative advantage in the East Asia will become similar each other with different catch-up process (Kojima, 1995). The analysis of general patterns of comparative advantage empirically shows what commonly believed in the flying geese paradigm.

International production fragmentation has become an interesting phenomenon ${ }^{10}$ in the ASEAN+3 region. It is defined as cross-border dispersion of component production/assembly within vertically integrated production process, with each country specializing in particular stage of production sequence (Athukorala and Yamashita, 2006). The international production sharing is strongly supported by the belief that the most important determinant of productivity (economies of scale) or unit costs is not the size of plant but the management of production within a plant of a given size. Having this large number of production sharing activities, East Asia is sometimes called East Asia's de facto economic integration. Intraregional trade, especially in parts and components industries, has increased significantly ( $\mathrm{Ng}$ and Yeats, 2003). Assembly activities have also increased drastically in the region. Gaulier et al. (2006) noted that vertical production/ distribution networks in the region have formed a "triangular trade" pattern, where the multinational corporations (MNCs) use China as an export base for the final assembly, in order to export final goods to the United State (US) and the European Unions (EU). Kimura (2006) argued that the pattern of industrial location and international trade has drastically evolved since the 1990s.

\footnotetext{
${ }^{10}$ The alternative names are frequently used such as 'vertical specialization' (Hummels et al. 2001, Yi 2003), 'slicing the value chain' (Krugman, 1995).
} 
The comparative advantage patterns should be considered in dynamic sense. Redding (2004) noted that comparative advantage is endogenously determined by past technological change, while simultaneously shaping current rates of innovation. The dynamic of comparative advantage might also caused by the role of input trade (Jones, 2000), friction in international trade and investment flows due to geography, institutions, transport, and information cost (Venables, 2001), the transmission of knowledge across borders (Grossman and Helpman, 1991), technological differences across border (Trefler, 1995), and monopolistic competition in differentiated products with increasing return to scale (Krugman, 1979).

\section{Conclusions}

In the ASEAN +3 , the increases in overall average RSCA index together with the decreases in its standard deviation imply that the increases in overall comparative advantage are encouraged by the higher increases in comparative advantage of products, which had no or lower comparative advantage in the past. The ASEAN, China and Korea may have a trade-off between specialization in the goods with comparative advantage (in low technological groups of products) and specialization in the other products with much potentiality for comparative advantage in the future as the result of high productivity growth as seen in the case of Japan.

There have been changes in the patterns (rank orders) of comparative advantage. The ASEAN has exhibited the most significant changes in the patterns of comparative advantage followed by China, Korea and Japan. However, the rates of changes have decreased since their comparative advantages become more concentrated on the products of manufacture. The pattern of comparative advantage of ASEAN is becoming similar with that of Japan. This catching up process has been spurred by the changes in the patterns of comparative advantage in both ASEAN and Japan due to Japan's foreign direct investment (FDI) in the ASEAN countries, which is more pro-trade-oriented type, and in the advanced countries, which is more anti-trade-oriented one. However, there is no steady-state or stationary level in similarities of the patterns of comparative advantage between the ASEAN and Japan, the ASEAN and Korea, as well as the ASEAN and China. Therefore, this confirms the argument saying that the comparative advantage should be considered in the dynamic sense instead of static one. 


\section{Acknowledgements}

The paper is an extended version of the paper that was presented at the International Studies Association (ISA)-Annual Convention in San Francisco, CA, USA, March 26-29 ${ }^{\text {th }}, 2008$. The author would like to thank Professors Masumi Hakogi, Reiko Hakogi, Ken Morita and participants of the convention for the comments. The author would also like to thank the referee (Takashi Isogai-Bank of Japan) for the comments and suggestions. Any remaining error, however, is the authors.

Received 23 June 2008, Revised 31 December 2008, Accepted 08 January 2009 


\section{References}

Akamatsu, K.(1961), "A Theory of Unbalanced Growth in the World Economy", Weltwirtschaftliches Archiv, 86, pp. 196-217.

Akamatsu, K.(1962), "A Historical Pattern of Economic Growth in Developing Countries", The Developing Economies, 1, pp. 3-25.

Athukorala, P. and N. Yamashita,(2006), "Production Fragmentation and Trade Integration: East Asia in a Global Context", North American Journal of Economic and Finance, 17(3), pp. 233-256.

Balassa, B.(1965), "Trade Liberalization and 'Revealed' Comparative Advantage", The Manchester School of Economics and Social Studies, 33(2), pp. 99-123.

Balassa, B. and M. Noland(1989), "The Changing Comparative Advantage of Japan and the United States", Journal of the Japanese and International Economies, 3(2), pp. 174-188.

Barnes, J., R. Kapplinsky and M. Morris(2004), "Industrial Policy in Developing Economies: Developing Dynamic Comparative Advantage in the South African Automobile Sector", Competition \& Change, 8(2), pp. 153-172.

Batra, A. and Z. Khan(2005), "Revealed Comparative Advantage: an Analysis for India and China", Working Paper No. 168, The Indian Council for Research on International Economic Relations(ICRIER).

Dalum, B., K. Laursen and G. Villumsen(1998), "Structural Change in OECD Export Specialization Patterns: De-specialization and 'Stickiness", International Review of Applied Economics, 12, pp. 447-467.

Elliot, R. J. R. and K. Ikemoto(2004), "AFTA and the Asian Crisis: Help or Hindrance to ASEAN Intra-regional Trade?", Asian Economic Journal, 18(1), pp. 1-23.

Enders, W.(1995), Applied Econometric Time Series, Canada: John Wiley \& Sons, Inc.

Fouquin, M., D. Hiratsuka and F. Kimura(2006), "Introduction: East Asia's de Facto Economic Integration”, in Hiratsuka, Daisuke(ed.), East Asia's de facto Economic Integration, New York: Palgrave Macmillan, pp. 1-15.

Gaulier, G., F. Lemoine and D. Ü Kesenci(2006), "China's Specialization in East Asian Production Sharing”, in Hiratsuka, D.(ed), East Asia's de Facto Economic Integration, New York: Palgrave Macmillan, pp. 135-180.

Grossman, G. M. and E. Helpman(1991), "Trade, Knowledge Spillovers, and Growth", NBER Working Paper No. W3485.

Gujarati, D.(1995), Basic Econometric, $3^{\text {rd }}$ Edition, New York: McGraw Hill.

Hinloopen, J. and C. Marrewijk(2001), "On the Empirical Distribution of the Balassa Index”, Weltwirtschaftliches Archiv, 134(1), pp. 1-35.

Hinloopen, J. and C. Marrewijk(2004a), "Empirical Relevance of the Hilman Condition and Comparative Advantage", Tinbergen Institute Working Paper 04-019/2.

Hinloopen, J. and C. Marrewijk(2004b), "Measuring Trade Dynamic", Tinbergen Institute, mimeo. 
Hinloopen, J. and C. Marrewijk(2004c), "P-P Plots and the Harmonic Mass Index: an Application to Comparative Advantage", Tinbergen Institute, mimeo.

Hinloopen, J. and C. Marrewijk(2004d), "Dynamic of Chinese Comparative Advantage", Tinbergen Institute Working Paper TI 2004-034/2.

Hoy, M., J. Livernois, C. McKenna, R. Rees, and T. Stengos(1996), "Mathematics for Economics", Canada: Addison-Wesley Publishers Limited.

Hummels, D., J. Ishii and K. Yi(2001), "The Nature and Growth of Vertical Specialization in World Trade", Journal of International Economics, 54(1), pp. 75-96.

International Monetary Fund(IMF)(1998), Direction of Trade Statistics(DOTS), Washington, D.C: IMF.

International Monetary Fund(IMF)(2006), Direction of Trade Statistics(DOTS), Washington, D.C: IMF.

Isogai, T., H. Morishita, and R. Rüffer(2002), “Analysis of Intra- and Inter-regional Trade in East Asia: Comparative Advantage Structures and Dynamic Interdependency in Trade Flows", International Department Working Paper Series 02-E-1, Bank of Japan, Tokyo, Japan.

James, W. E. and O. Movshuk(2003), "Comparative Advantage in Japan, Korea, and Taiwan between 1980 and 1999: Testing for Convergence and Implications for Closer Economic Relations", The Developing Economies, XL1-3, pp. 287-308.

Jones, R. W.(2000), Globalization and the Theory of Input Trade, Cambridge: MIT Press.

Junz, H. B. and R. R. Rhomberg(1965), "Prices and Export Performance of Industrial Countries", 1953-63, International Monetary Fund, Staff Papers XII (July), pp. 224269.

Kimura, F.(2006), "The Development of Fragmentation in East Asia and Its Implications for FTAs", in Hiratsuka, D.(ed), East Asia's De Facto Economic Integration, New York: Palgrave Macmillan, pp. 16-31.

Kojima, K.(1995), "Dynamics of Japanese Direct Investment in East Asia", Hitotsubashi Journal of Economics, 36, pp. 93-124.

Krugman, P.(1995), “Growing World Trade: Causes and Consequences”, Brooking Papers on Economic Activity, 25 ${ }^{\text {th }}$ Anniversary Issue, pp. 327-377.

Krugman, P.(1979), "Increasing Returns, Monopolistic Competition, and International Trade", Journal of International Economics, 9, pp. 469-479.

Laursen, K.(1998), "Revealed Comparative Advantage and the Alternatives as Measures of International Specialization”, DRUID Working Paper, No 98-30, Danish Research Unit for Industrial Dynamics (DRUID).

Leu, M. G. J.(1998), "Changing Comparative Advantage in East Asian Economies", SABRE Working Papers 3-98, School of Accountancy and Business Research Centre.

MacKinnon, J. G.(1996), "Numerical Distribution Functions for Unit Root and Cointegration Tests", Journal of Applied Econometrics, 11, pp. 601-618.

Mansfield, E.(1994), "Statistics for Business and Economics: Methods and Applications", 5th Edition. New York: W.W. Norton \& Company, Inc. 
Masuyama, S.(1997), "The Evolving Nature of Industrial Policy in East Asia: Liberalization, Upgrading and Integration”, in Masuyama, S., D. Vandenbrink and C. S. Yue(eds.): Industrial Restructuring in East Asia. Towards the $21^{\text {st }}$ Century, Institute of Southeast Asian Studies(ISEAS), Singapore and Nomura Research Institute(NRI), Japan, pp. 3-18.

McClave, J., T. Benson, P. George and T. Sincich(2001), Statistics for Business and Economics, $8^{\text {th }}$ Edition, International Edition, Upper Saddle River Prentice Hall International.

McCarthy, D. M. P.(2006), International Economic Integration in Historical Perspective, New York: Routledge.

Nelson, R. R.(1977), "Technological Change and Factor Mix over the Product Cycle: a Model of Dynamic Comparative Advantage", Journal of Development Economics, 4(1), pp. 3-24.

Ng, F. and A. Yeats(2003), "Major Trade Trends in East Asia: What are their Implications for Regional Cooperation and Growth?", Policy Research Working Paper, The World Bank, Development Research Group Trade, June.

Proudman and Redding(2000), "Evolving Patterns of International Trade", Review of International Economics, 8(3), pp. 373-396.

Redding, S.(2002), "Specialization Dynamics", Journal of International Economics, 58, 299-334.

Roland, D. H.(2003), "East Asian Pattern of Comparative Advantage”, ADB Institute Research Paper Series No. XX.

Todaro, M. and S. Smith(2006), Economic Development, $9^{\text {th }}$ Edition. Addison-Wesley series in economics.

Trefler, D.(1995), "The Case Missing Trade and Other Mysteries", American Economic Review, 85(5), pp. 1029-1046.

Venables, A. J.(2001), Geography and International Inequalities; the Impact of New Technology, Paper Prepared for ABCDE, World Bank, Washington DC.

Viner, J.(1950), The Custom Union Issue, New York: Carnegie Endowment for International Peace.

Wörz, J.(2005), "Dynamic of Trade Specialization in Developed and Less Developed Countries", Emerging Markets Finance and Trade, 41(3), pp. 92-122.

Yi, K.(2003), "Can Vertical Specialization Explain the Growth of World Trade", Journal of Political Economy, 111(1), pp. 52-102. 